\title{
GCU
}

Glasgow Caledonian

University

University for the Common Good

\section{Beyond aspirations: deploying the capability approach to tackle the under- representation in higher education of young people from deprived communities}

Campbell, Laurie Anne; McKendrick, John $\mathrm{H}$.

Published in:

Studies in Continuing Education

DOI:

$10.1080 / 0158037 X .2017 .1293630$

Publication date:

2017

Document Version

Author accepted manuscript

Link to publication in ResearchOnline

Citation for published version (Harvard):

Campbell, LA \& McKendrick, JH 2017, 'Beyond aspirations: deploying the capability approach to tackle the under-representation in higher education of young people from deprived communities', Studies in Continuing Education, vol. 39, no. 2, pp. 120-137. https://doi.org/10.1080/0158037X.2017.1293630

\section{General rights}

Copyright and moral rights for the publications made accessible in the public portal are retained by the authors and/or other copyright owners and it is a condition of accessing publications that users recognise and abide by the legal requirements associated with these rights.

Take down policy

If you believe that this document breaches copyright please view our takedown policy at https://edshare.gcu.ac.uk/id/eprint/5179 for details of how to contact us. 


\section{Beyond Aspirations: Deploying the Capability Approach to tackle the under-representation in Higher Education of young people from deprived communities}

Laurie Anne Campbell and John H. McKendrick

Glasgow School for Business and Society, Glasgow Caledonian University, 70

Cowcaddens Road, Glasgow, Scotland, G4 OBA

Email: Laurie.annecampbell@gcu.ac.uk

Email: jmke@gcu.ac.uk

Laurie Anne Campbell is a doctoral research student at Glasgow Caledonian University. Her research interests include widening participation and attracting diversity in higher education.

John Holland McKendrick is a Professor at Glasgow Caledonian University with interests in understanding and tackling child poverty. Much of his work explores the role of education in anti-poverty strategies. 


\section{Beyond Aspirations: Deploying the Capability Approach to tackle the under-representation in Higher Education of young people from}

\section{deprived communities}

This paper re-examines the low participation of young people from deprived communities through the lens of the Capability Approach. A fundamental problem for tackling widening participation is that much of the thinking of policymakers is grounded on the flawed 'poverty of aspiration thesis'. This paper contends that Sen's Capability Approach' $(1992,1999)$ offers a better way of theorising and understanding the persistent underrepresentation in Higher Education of young people from deprived communities. A comparative case study approach was conducted in two secondary schools in Scotland, each serving a deprived area, each of which has an intervention programme that promotes higher education. The study employed mixed methods (i.e. questionnaires and interviews) to investigate young people's aspirations and perceptions of their capabilities. The findings confirm findings from previous studies that are critical of the 'poverty of aspirations' thesis, which suggest that young people have high aspirations. However, an understanding of this is enriched when appraised within the framework of the Capability Approach, as aspirations are rationalised against findings, which demonstrate that these same young people are also confident in their capabilities and that social arrangements are instrumental in supporting capability development.

Keywords: Aspirations; Capability Approach; Widening Participation; Young People; Scotland; Deprived Communities 


\section{Introduction}

Widening participation has been at the forefront of Higher Education strategies and policies in advanced economies such as the UK for the last twenty years. The fundamental premise of 'widening participation' is that there is a population that has the potential to achieve more from the education system than at present. The 'participation gap’ has been rationalised through deficits models, whereby progress toward more equitable outcomes tends to be articulated in terms of either addressing the problems of under-achieving young people (e.g. raising aspirations, raising attainment) or reconfiguring the education system to avoid disadvantaging able candidates from more deprived backgrounds who tend to be less well positioned in terms of criteria traditionally used to determine eligibility (e.g. introducing contextualised admissions, articulation from college). The interconnections between this double deficit are acknowledged and embedded in many of the widening participation projects initiated by universities (Bok, 2010; Gale and Parker, 2015). Some observers acknowledge the underlying structural causes of inequitable educational outcomes (Sellar, 2015; Sellar et al., 2011), although these are, at best, accorded a marginal role in policy and strategy to widen participation in higher education.

In particular, 'raising the aspirations' of under-achieving young people from deprived backgrounds has been a cornerstone of widening participation policy (Sinclair et al., 2010), despite an accumulated body of research that suggests that the 'poverty of aspirations’ thesis is inherently flawed (McKendrick et al., 2007; Schischka, 2014; Sellar et al., 2011; Spohrer, 2011, 2015; Zipin et al., 2015). 
Following Hart (2016), this paper argues the need for a more nuanced interpretation of aspirations in debates on widening participation; it is proposed that there is a need to move beyond both unquestioning belief in the 'poverty of aspirations' thesis on one hand, and outright dismissal of it on the other, to appreciate the way in which it is entwined as both cause and effect of young people's preparedness for higher education, and inclination toward it. A practical application of Sen’s Capability Approach (1999) is offered, which provides a richer conceptualisation of, and the means to better understand, the now persistent underrepresentation of young people from deprived communities in the case study of Scottish higher education.

Briefly, by way of introduction, the context for the case study is presented. Next, the paper reviews deficit thinking in widening participation debate, paying particular attention to how the 'poverty of aspirations' thesis has persisted, despite critique. The Capability Approach is then proposed as a means of providing a more fruitful way to rationalise aspirations in widening participation work. An illustration is then provided of how the Capability Approach can be operationalised to better understand young people from a deprived community's post-school aspirations and how social arrangements impact on capability development and aspiration formation. The wider significance for policy is considered in conclusion.

\section{The Scottish Context}

Education is a devolved responsibility of the Scottish Government within the UK political system (Keating, 2005). Nevertheless, there has been a shared concern 
throughout the UK with widening participation for several decades, the early commitments to which were strengthened by both governments in the UK and Scotland sharing similar political complexion and educational philosophy in the early years of Scottish devolution. Widening participation initiatives such as the Excellence in Cities directive (DfES, 2005) and Aim Higher (HM Treasury, 2007) were developed on the understanding that widening participation would increase employment; improve productivity; and promote social justice by narrowing the class gap in educational attainment (Burke, 2012). The pinnacle of 'widening participation' as an education policy goal was articulated in the form of a target (never attained) by the then Labour government to achieve 50 percent of young people aged 18-30 in higher education by 2010 (Public Accounts Committee, 2009). Indeed, the Scottish Funding Council (2015) reports that there has only been a one per cent increase in the number of young people partaking in higher education from the top 20 most deprived areas since 2010, with Parker (2012) observing that the higher education participation rates of young people from deprived communities are lower than anywhere else in the UK.

In recent years, there has been more policy divergence between the UK and Scottish governments (Keating, 2005). Against a weakening of social justice objectives for the UK as a whole (MacKinnon, 2015), the nationalist Scottish Government has strengthened its commitment to widen participation through measures such as the Scottish Attainment Challenge (Education Scotland, 2016), which aims to close the gap in attainment between secondary schools and by requiring higher education institutions to specify activity leading toward and targets to measure progress in widening participation for Scottish domiciled students (Scottish Funding Council, 2016). The on- 
going commitment to widen participation in Scottish higher education necessitates a rethinking of the deficit thinking that has, as yet, failed to deliver a step-change in widening participation outcomes.

\section{Deficit Thinking in and Beyond the 'Poverty of Aspirations' Thesis}

The 'poverty of aspirations' thesis is built upon the premise that young people from deprived communities have absolutely low aspirations and relatively lower aspirations than their non-deprived peers. Some rationalise this 'poverty of aspirations' in the context of wider changes in global society (Bauman 1998; Brown 2011; Brown 2013) in which neoliberal thinking and a belief in meritocracy asserts that aiming high and working hard will result in economic rewards (Spohrer, 2015; Zipin et al., 2015). Failure to aspire is then more often than not attributed as the failing of an individual, rather than a structural condition (Archer, 2007).

The 'aspirations deficit' has been a pervasive grounding for policy makers in the UK, embraced both by those concerned to promote social justice and, more recently, by those more concerned to transform failing families (Shildrick et al., 2016). A key goal of the widening participation agenda becomes the quest to instil a culture of aspirations amongst young people from deprived communities to raise educational attainment and achieve progression to more advanced levels of learning. Early discourses of the poverty of aspirations thesis began to appear in policy documents from around 1997, most notably in the Dearing Report (National Committee of Inquiry into Higher Education, 1997) and in From Elitism to Inclusion: Good practice in Widening Access 
to Higher Education (Woodrow et al., 1998). In 2008 the UK government did acknowledge that aspirations amongst young people from different socio-economic backgrounds were in fact, similar: “[D]isadvantaged young people do not have fundamentally different aspirations from their more adapted peers” (Social Exclusion Taskforce, 2008: 10). However, the following year in a report to the Cabinet Office, the focus of the same Taskforce reverts back to raising aspirations: "[U]ltimately, it is the aspirations people have to better themselves that drives social progress' (Millburn, 2009: 6). The framing of aspirations remains a key driver of political agenda and policy, despite a growing body of literature demonstrating high aspirations among disadvantaged young people (Cuthbert and Hatch, 2009).

It would be wrong to dismiss the relevance of low aspirations to educational outcomes. For example, studies have reported relationships between low aspirations and educational achievement (Gutman and Ackerman, 2008), as well as subjective poverty (Copestake and Camfield, 2010). It is also suggested that parental influence affects aspiration formation; Aiming High (HM Treasury, 2007) states that parents from lower socio-economic groups or with lower level qualifications are more likely to think their children will 'peak' at GCSEs than parents from higher social classes or those with higher qualifications. Similarly, Goodman and Greggs (2010) found that mothers’ aspirations are especially important during a child’s primary school years with 81 percent of the affluent mothers anticipating that their nine-year-olds would attend university, compared with 37 percent of less affluent mothers. Of particular note is that these later studies tend to suggest a positive correlation between parental socioeconomic background and aspirations. On the other hand, not all would concur with this evidence (and therefore that parental attitudes contribute to variances in aspirations or 
achievement): Cuthbert and Hatch’s (2009) longitudinal case study concluded that that almost all parents projected positive aspirations for their children regardless of their social position, contradicting the evidence which suggests that low parental aspirations will lead to low aspirations for children.

Studies working with young people also question the existence of a 'poverty of aspirations'. Atherton et al. (2009) reported that at the age of 12, disadvantaged young people have high aspirations. Similarly, Cummings et al. (2012) found that most youth (and their parents) have high aspirations and attach great importance to education and want to go to university or to attain professional jobs irrespective of barriers and constraints they may face. Furthermore, Gutman and Ackerman (2008), argue that although constraints have a major impact on aspirations, these do not materialise until the post-school years (between the ages of 18-21) as low-paid/skilled jobs becomes a reality for some.

For the avoidance of doubt, critiquing the 'poverty of aspirations' thesis is not to dismiss the existance of any social patterning in aspirations. Indeed, analysis of largescale datasets (Croll, 2009; Strand, 2014) have demonstrated that there is a class differential; more young people from more economically advantageous backgrounds aspire to continue with post-school education. Rather, it is primacy of the 'poverty of aspirations' thesis, with its presentation as the explanatory framework to guide interventions that is so problematic. As both research with children from multiply deprived neighbourhoods and comparative research across the socio-economic spectrum confirm, the vast majority of young people from deprived neighbourhoods have what 
might be considered 'high aspirations', the levels of which are far in excess of the numbers who progress to post-school education.

Furthermore, 'poverty of aspirations' is not the only deficit that has been identified in aspirational research. St. Clair and Benjamin (2011) argue that aspirations are embedded within social contexts and are therefore influenced by structural constraints and social expectations. Similarly, Kintrea et al. (2011) explored disadvantaged young people’s aspirations across London, Glasgow, and Nottingham and found that they aspire for university, and professional careers yet were constrained by a lack of academic places. Thus, those from disadvantaged backgrounds with high educational aspirations are not always presented with the opportunity to take such pathways. Interestingly, there is evidence that cultural constraints have a negative impact on the capacity to aspire. A lack of confidence and self-efficacy can result in disadvantaged young people forming low aspirations as they often feeling uncomfortable within the university environment, which is shaped predominantly by middle-class culture and values (Hutchings and Archer 2001; Johnson et al. 2007; Reay et al., 2010). Connor et al. (2001) found that students from lower socioeconomic backgrounds lacked the confidence to perform in a higher education environment in comparison with their 'middle' class counterparts. This evidence suggests that aspirations cannot be attributed to individual agency alone.

It is evident that social, economic and cultural factors affect, shape and form aspirations. Aspirations are to some extent, an important element with regards to altering social circumstances, although the 'poverty of aspiration' thesis presents a weak claim as the primary or overarching framework for policy. Rather than dismiss outright 
the importance of aspirations, and rather than give primacy instead to a 'cultural/structural deficit', it is argued that the Capability Approach can be used as an evaluatory framework, which affords a more comprehensive analysis of disadvantaged young people’s post-school choices by investigating the interaction of the array of factors that influence decision-making.

\section{The Capability Approach as a means to understand young people's under- representation in Higher Education}

The Capability Approach was introduced by Sen $(1992,1999)$ and developed by Nussbaum (2000) as an alternative approach to dominant theories of social justice which, according to Sen, provided only a limited explanation for inequality and wellbeing. The primary of objective of the Capability Approach is to pursue human development by evaluating what people can do or be. In the Capability Approach, the focus is on an individual's ability to convert resources into valuable achievements within the social and political context of any given society, shifting analysis towards evaluating the conditions within which individuals can create opportunities to expand their capabilities. The economy (commodities) is viewed as a resource through which capabilities develop (potential achievements) to allow for functions (actual achievements) that provide utility (value to a person's life).

Functionings are the "ability to do valuable acts or reach valuable states of being” (Sen, 1999: 30), and can range from the elementary (such as maintaining good health or comfortably supporting a family) to the complex (such as active participation in society or the ability to make reasoned choices). Functionings cannot be achieved 
without capabilities, which hold instrumental value in the sense that they assist in the achievement of significant goals. The potential opportunities available to any given person that assist in acquiring valuable outcomes is defined as a capability set. The list of capabilities available to a person is extensive and can include being able to get a decent job, having a family, accessing education, living a life free of discrimination and practising faith. For Robeyns (2005) the key distinction that the Capability Approach makes is the variation between intrinsic or instrumental value (the difference between capabilities and functions) or to put simply, opportunities to achieve and achievements. This shifts away from the dominant school of thought in which individuals and what they produce are the means to an end.

For Sen (1992: 58), people are dependent on agency to pursue their 'personal values and objectives’. In a further acknowledgment of human diversity, Sen (1999) also recognises that there are variations amongst individuals concerning their abilities to convert capabilities to functions. Thus, people are active agents who can bring about social change, although Burchardt and Vizard,2011) caution that agency depends on autonomy that will allow for empowerment and choice. It can be surmised then that if agency does not develop, neither will the ability to pursue goals. Potential unrealised may reflect the lack the resources to achieve this, and/or the knowledge how to use such resources, and/or the motivation and confidence to apply such resources (Hollywood et al., 2012). All aspects must be considered in an approach that, therefore, can offer valuable insight into the non-participation of young people from deprived communities in higher education. 
There has already been some useful application of the Capability Approach in the field of education (e.g. Terzi, 2007; Walker \& Unterhalter, 2007; Hart, 2007, 2008, 2009, 2012a, 2012b). Watts and Bridges (2006) found that young people might value other options that do not include University concluding that policymakers often fail to recognise the aspirations of those who do not choose higher education pathways; a conclusion also reached by Hart (2012a) in her analysis of Aim Higher. Indeed, Hart suggests that some young people felt compelled to choose higher education as a post school pathway resulting in agency freedom constraint. The work of both Watt and Bridges and Hart is indicative of the value of the Capability Approach while maintaining a focus on aspirations.

Nevertheless, there are still debates surrounding the validity and utility of the Capability Approach (Ysander, 1993, Robeyns, 2005, Stewart, 2005, Burchardt \& Vizard, 2011). Additionally, there is divergent opinion over capability lists (Sen, 1999, Nussbaum, 2000, Robeyns, 2005). Sen (1999: 44) argues that there are basic capabilities such as being well-nourished, well-sheltered, in good health and being educated which are, 'are a relatively small number of central beings and doings'. However, he expresses concern that lists are undemocratic and once created become fixed and difficult to change. If they must exist, Sen contends that they should be created through a democratic process. Conversely, Nussbaum (2000) advocates for a universal list of capabilities and suggests a list of ten items that are necessary for human flourishing, i.e. life expectancy, bodily health, bodily integrity, senses imagination and thought, emotions, practical reason, affiliation, other species, play, and control over one’s environment. For Robeyns (2005), lists should be context-specific to ensure they are representative of what is being evaluated. Her position is consistent with Sen's in 
that context-specific capabilities should be identified through democratic process involving the people with which the capabilities are concerned. Following Robeyns, Walker (2006: 128-129) developed a list of eight capabilities for success in Higher Education, i.e. practical reasoning; educational resilience; knowledge and imagination; learning disposition; social relations and social networks; respect, dignity and recognition; emotional integrity and emotions; and bodily integrity. Walker's capability set is used in this paper as a framework for operationalizing the Capability Approach.

\section{Methodology}

This comparative case study deployed a sequential mixed method design (questionnaires, followed by semi-structured interviews) to explore the importance of capabilities and aspiration in understanding positioning in relation to higher education of young people living in deprived areas.

The research was administered in two secondary schools, each serving a catchment that was determined to be among the most deprived areas in Scotland according to the latest Scottish Index of Multiple Deprivation (Scottish Government, 2016) and which had a similar profile in terms of the low percentage of young people transitioning to higher education (Table 1). Both schools had access to widening participation intervention programmes, which is relevant in the context of seeking to understand the impact of social arrangements on a young person's ability to pursue positive post-school choices. Applebee's involvement in widening participation activity was more extensive than Shepherdton's, comprising whole year group activities in $1^{\text {st }}$, 
$3^{\text {rd }}$ and $5^{\text {th }}$ year, with targeted interventions open to prospective university applicants in the $5^{\text {th }}$ and $6^{\text {th }}$ year. Shepherdton's intervention concentrated on the later school years and involved targeted support for students who had shown some potential.

Table 1: Pupils’ Post-School Educational Destinations from Participating Schools (Campbell, 2016).

(Insert Table 1 about here)

The questionnaire was developed in two stages, in a democratic manner consistent with the Capability Approach, as advocated by Sen (2004) and Robeyns (2005). First, 45 stakeholders involved in widening participation in Scotland were identified from five strategic clusters ( $n=9$ per clusters): (i) national strategic concern with widening participation (WP) (ii) specialist knowledge in the field of WP (iii), university sector with an interest in promoting WP (iv) school sector with specific interest in promoting WP and (v) ex-pupils from schools in deprived areas. Each was consulted and invited to complete an online questionnaire to canvass opinion on the relevance to Scotland of the factors that comprised Walker's capability list for success in higher education. The questionnaire achieved a 40 percent response rate with multiple contributions from each strategic cluster and validated the capability clusters that were proposed.

Indicators were then selected for each capability cluster, drawing from three established questionnaires, i.e. the National Survey of Student Engagement of the Higher Education Academy, which evaluates the level and quality of effort that students invest in their studies (Buckley, 2013); the Strengths and Weakness questionnaire, a 
behavioural screening questionnaire for 3-16 year olds comprising of items to measure psychological attributes in relation to wellbeing (Goodman 1997); and the California Healthy Kids Survey, which aimed to measure the wellbeing of young people in secondary school (Constantine et al., 2001). To minimise response bias, one positively worded and one negatively worded statement were used per cluster and statements were presented in random order. Furthermore, a duplicate indicator was also placed within the capability set 'Knowledge and Imagination' as a quality check.

The research sample young people aged 12-16 from deprived communities who had access to some form of intervention programme. This age group is significant in terms of young people making the transition into independent thinkers who are active agents in making their own choices (Biggeri et al., 2010). The research focused specifically on year groups S2 and S4 as it is during these periods that young people are given the opportunity to make independent decisions about their future in term of subject choice, which in turn influences post school pathway. The online questionnaires were conducted in school as part of the student's skills lab class and took an average of 12 minutes to complete. The survey canvassed opinion on young people's perception of their own capabilities, the influence of others in making post-school choices and the impact of intervention activities before and after participation. From a target population of 413,330 students completed surveys ( $80 \%$ response rate). There was an even distribution of returns by gender ( $46 \%$ girls, $50 \%$ boys; and $4 \%$ rather not say) and age stage (48\% from S4 and 52\% from S2), although more surveys were returned from Shepherdton (35\% from Applebee and 66\% from Shepherdton). 
Following preliminary analysis of the questionnaires, potential candidates for interviews were identified from those who had expressed an interest in the questionnaire in presenting for a follow-on interview. These semi-structured interviews sought a deeper understanding of young people’s aspirations and capability perception, as well as providing the means to explore of who or what was seen to enable or constrain young people regarding making positive post-school choices. Interviewees were selected based on survey responses. The criteria consisted of aspirational choice - further/higher education or work, level of participation in intervention activities plus year group, and gender. Overall, 33 semi-structured interviews were conducted, 21 at Applebee and 12 at Shepherdton. Statistical survey results were compared with interview themes to illuminate the relationship between aspirations, post-school choices, and capabilities. A thematic analysis was undertaken of the interview data using predetermined subjects developed from the questionnaire.

\section{Findings}

The research examined the possession of capabilities of young people from deprived communities, their post-school aspirations and the impact of social arrangements such as widening access initiatives, and networks of influence on aspiration formation.

\section{Pupils with Capability}

Far from being a less able population, the research suggests that young people from deprived communities are confident in having the specific skills and qualities that may 
enable the pursuit of positive post-school choices (Table 1); positive, and often strongly positive, responses were returned for fourteen of the sixteen capability indicators and, in aggregate, more positivity than negativity was expressed for each of the eight capability clusters. For example, for the 'learning dispositions' cluster, 93\% agreed or strongly agreed that they "liked to be able to improve their learning" and 86\% disagreed that they were "not really interested in learning new things". As noted by Hart (2012a), there is a positive association between aspiration realisation and learning dispositions.

Figure 1: Positivity and negativity in young people's perceptions of their capabilities, by capability cluster (Campbell, 2016).

Table 1: Pupils’ Post-school Educational Destinations from Participating Schools

\begin{tabular}{|l|c|c|}
\hline & Applebee & Shepherdton \\
\hline Locality & Glasgow & Ayrshire \\
\hline No. of Enroled Pupils, 2015 & 395 & 625 \\
\hline No. of Teachers, 2015 & 52 & 58 \\
\hline \% of School Leavers Entering HE (school) & $23 \%$ & $20 \%$ \\
\hline $\begin{array}{l}\text { \% of School Leavers Entering HE (locality), } \\
\text { 2014/15 }\end{array}$ & $32 \%$ & $33 \%$ \\
\hline $\begin{array}{l}\text { \% of School Leavers Entering HE (Scotland), } \\
\text { 2014/15 }\end{array}$ & \multicolumn{2}{|c|}{$37 \%$} \\
\hline \% of School Leavers Entering FE (school) & $18 \%$ & $27 \%$ \\
\hline $\begin{array}{l}\text { \% of School Leavers Entering FE (locality), } \\
\text { 2014/15 }\end{array}$ & $25 \%$ \\
\hline $\begin{array}{l}\text { \% of School Leavers Entering FE (Scotland), } \\
\text { 2014/15 }\end{array}$ & \multicolumn{2}{|c|}{} \\
\hline
\end{tabular}

Sources: Education Scotland, (2015, 2016).

Notes: Follow-up destination statistics are used in the table.

'Practical reasoning' and 'knowledge' might be considered to be especially relevant to the development of aspirations. As with learning dispositions, strongly positive responses were expressed for both indicators of 'practical reasoning' and 'knowledge', further supporting the position that young people have high aspirations and value education as a pathway to achieving them. 
On the whole, there was very little variation across schools and only very specific differences according to gender. Pupils from Applebee were more negative than pupils from Shepherdton with regards to "whether school work was affected by other things going on in life" 1 and when considering whether they "liked to improve their learning”2, but were more positive than those from Shepherdton when expressing their opinion on whether "what was learned at school mattered in the real world" 3 . In terms of gender, girls were more positive than boys with regard to "I respect other people's opinions, even if they are different from my own”, but were more negative than boys in relation to being "nervous in new situations and easily losing confidence" ${ }^{4}$ and being "afraid of being hurt by others at school" . Previous research has found that young people are more likely to achieve positive outcomes when they develop ambition, achievable aspirations, combined with the self-esteem and self-efficacy (Social Exclusion Taskforce, 2008). In this respect, the gender differences may be important in shaping young people's futures in terms of their ability to convert personal factors into capabilities that can shape future functionings.

${ }^{1}$ 53\% of pupils from Applebee agreed, compared to only 34\% from Shepherdton (a difference that was significant at the $99 \%$ confidence level)

2 95\% of pupils from Shepherdton agreed, compared to only 88\% from Applebee (a difference that was significant at the $95 \%$ confidence level)

${ }^{3}$ 88\% of pupils from Applebee disagreed, compared to 'only' $76 \%$ of those from Shepherdton (a difference that was significant at the 95\% confidence level).

${ }^{4} 63 \%$ of girls agreed, compared to $43 \%$ of boys (a difference that was significant at the $99 \%$ confidence level)

${ }^{5} 69 \%$ of boys disagreed, compared to $53 \%$ of girls (a difference that was significant at the $95 \%$ confidence level) 
A wider range of differences was evident for age stage, with the younger S2 pupils expressing more positivity than the older S4 pupils for seven of the sixteen indicators. Differences were marked for the 'respect, dignity and recognition' capability clusters. Here, more S2 pupils expressed capability for both indicators, i.e. $90 \%$ of S2 pupils opined that they "respected other people’s opinions, even if they were different from their own”, compared to ‘only' $77 \%$ of S4 pupils ${ }^{6}$ and only $10 \%$ of S2 pupils agreed that they “didn't like it when other people disagreed with them”, compared to $20 \%$ of S4 pupils ${ }^{7}$.

From a capability perspective, S2 pupils display more wellbeing freedom than those in S4. That is, their own belief in their capability set allows them to actualise potential functionings through the development of their capabilities. However, this level of actualisation decreases in S4 as they progress towards achieving the overall functioning of achieving a positive post-school choice.

Notwithstanding the specific differences and without underplaying the significance of them, the key finding among these pupils from schools serving largely deprived areas is that the majority possess a capability set, which as suggested by Walker (2006), is the foundation for success in higher education given that these

${ }^{6}$ Chi-square $=11.135$; d.f. $=2$; No. of cells with E.F. $<5=0$; Significance $=0.004$. Cases $=$ 310.

${ }^{7}$ Chi-square $=7.696$; d.f. $=2$; No. of cells with E.F. $<5=0$; Significance $=0.021$. Cases $=301$. 
capabilities act as conversions into functionings. Almost all respondents indicated high

levels of confidence and thus, have the ability to form higher education aspirations.

\section{Educational Aspirations and Occupational End Goals}

On first impressions, the research seems to reinforce the body of knowledge that is critical of the 'poverty of aspirations' thesis (Table 2).

Table 2: Post-School Aspirations by School (Campbell, 2016).

Table 2: Positivity and negativity in young people's perceptions of their capabilities, by Capability cluster

\begin{tabular}{|c|c|c|c|c|c|c|}
\hline \multirow[b]{2}{*}{ Capability Cluster } & \multirow[b]{2}{*}{ Indicator } & \multicolumn{5}{|c|}{ Percentage of young people } \\
\hline & & $\begin{array}{l}\text { Strongly } \\
\text { negative }\end{array}$ & Negative & Neutral & Positive & $\begin{array}{l}\text { Strongly } \\
\text { positive }\end{array}$ \\
\hline Bodily integrity & I am afraid of being hurt by others at school $*$ & 11 & 20 & 33 & 28 & 29 \\
\hline Bodily integrity & I feel safe at school & 8 & 24 & 40 & 25 & 23 \\
\hline Educational resilience & $\begin{array}{l}\text { My schoolwork could be better but is affected by other things } \\
\text { going on in my life * }\end{array}$ & 31 & 26 & 27 & 7 & 53 \\
\hline Educational resilience & I believe I can achieve anything that I choose to do at school & 5 & 13 & 45 & 33 & 16 \\
\hline Emotional integrity & I am nervous in new situations and easily lose confidence * & 32 & 18 & 21 & 8 & 62 \\
\hline Emotional integrity & If something upsets me I tend not to show it & 13 & 19 & 37 & 26 & 28 \\
\hline Knowledge and imagination & What I learn at school doesn't matter in the real world * & 5 & 15 & 34 & 42 & 17 \\
\hline Knowledge and imagination & $\begin{array}{l}\text { I can connect what I've learned in school with things that are } \\
\text { happening in the world }\end{array}$ & 6 & 12 & 58 & 20 & 16 \\
\hline Knowledge and imagination & What I learn at school doesn't matter in the real world * & 4 & 15 & 37 & 42 & 14 \\
\hline Learning disposition & I'm not really interested in learning new things * & 3 & 7 & 44 & 42 & 11 \\
\hline Learning disposition & I like to be able to improve my learning & 3 & 3 & 40 & 53 & 6 \\
\hline Practical reason & School is not important to me ${ }^{*}$ & 4 & 6 & 36 & 49 & 12 \\
\hline Practical reasoning & What I do during school will make a difference to my future & 2 & 8 & 34 & 54 & 8 \\
\hline Respect, dignity, recognition & I don't like it when other people disagree with me * & 11 & 33 & 33 & 19 & 32 \\
\hline Respect, dignity, recognition & $\begin{array}{l}\text { I respect other peoples opinions even if they are different from } \\
\text { mine }\end{array}$ & 2 & 12 & 49 & 35 & 10 \\
\hline Social relations and networks & I prefer not get involved in group work * & 10 & 26 & 35 & 23 & 29 \\
\hline Social relations and networks & I enjoy working with others in class & 4 & 25 & 41 & 26 & 21 \\
\hline
\end{tabular}

Notes: (i) Young people responded to each statement using a five point scale ranging

from strongly agree through to strongly disagree. For ease of interpretation in this

Table, responses have been aligned in terms of whether responses were positive or

negative. Accordingly, and for example, strongly agree is reported as a strongly positive 
response for indicators without an asterisk; in contrast, strongly agree is a strongly negative response for those indicators with an asterisk.

Overall, the majority of young people in both schools indicated that they wish to continue in post-school education (73\%), with one-half (51\%) expressing a desire to pursue university studies and more than one-fifth seeking to pursue Further Education (21\%). It is evident that a substantial proportion of young people from deprived communities' express high aspirations for further study. During the interviews it became clear that the educational aspirations of the young people from deprived communities were directly linked to their occupational aspirations, i.e. post-school education is firmly understood as a means to an (occupational end), rather than an end goal of inherent merit in its own right, or indeed as a means to another associated goal (e.g. the student lifestyle):

I want to go to university to study law ... If you want to go to university, you'll need Higher [school-level qualifications in Scotland] to get into university, and if you've no' got an education, and you don't go to school, you're not going to get them (Applebee, Female, S2)

I want to join the police, and I've researched [it]. The qualifications first that I checked were Maths and English, and then you need to do some religious models .... I've already talked to my career advisor, and she said she's going to help me apply for certain college courses to help me get on the right track and so is the school police officer (Applebee, male, S4) 
I'd like to be an entrepreneur and have different businesses and properties... I want to stay until 6th year then I plan on going to university (Shepherdton, female, S4)

I want to become an engineer or possibly get a joiner or plumber apprenticeship I've no idea what I need to do, though, I think you probably need to go to college, I'm not a hundred percent (Shepherdton, male, S4).

As these extracts demonstrate, college and/or university education features prominently on many pupils' horizons. For some, post-school study is an essential pathway (Applebee, extracts), whereas for others it is perceived either to be desirable or likely to be required to achieve this functioning (the Shepherdton extracts). Thus, from a capability perspective, rather than 'aiming low' it can be surmised that young people value education and the role it could play in helping the achieve their desired functionings.

However, as these extracts demonstrate, a degree of uncertainty sometimes pervades over whether post-school education will assist in achieving the desired end goal. Further probing found that, particularly at Shepherdton, although there was awareness of university, there was a lack of understanding of the role it plays in achieving occupational aspirations:

I've thought about it [going to university/college], but I don't know what one would be better for me...I don't really know what they are, to be honest, I just really know what school is (Shepherdton, Male S2). 
I don't know like very high degrees; I don't know if that's what they're called? I think you need really good people skills and be able to do business plans, you do need a bit of a technical side too, you need most subjects that you do at school, (Shepherdton, female, S2).

Furthermore, the aggregate figures for both schools disguise significant differences in aspiration by age stage and gender; as Table 3 demonstrates, girls are much more likely than boys to aspire to university (60\% of girls, compared to $46 \%$ of boys) and aspirations toward post-school education fall between S2 and S4 (81\% of pupils to 66\% of pupils). 
Table 3: Post-School Aspirations by Gender and Age-Stage (Campbell, 2016).

Table 3: Post-School Aspirations by School

\begin{tabular}{|c|c|c|c|c|c|c|}
\hline & \multicolumn{2}{|c|}{ Applebee } & \multicolumn{2}{|c|}{ Shepherdton } & \multicolumn{2}{|c|}{ Overall } \\
\hline & $\%$ & No. & $\%$ & No. & $\%$ & No. \\
\hline Go to university & $50 \%$ & 55 & $52 \%$ & 113 & $51 \%$ & 168 \\
\hline Go to college & $23 \%$ & 25 & $20 \%$ & 44 & $21 \%$ & 69 \\
\hline Get a full-time job & $15 \%$ & 17 & $12 \%$ & 25 & $13 \%$ & 42 \\
\hline Get a part-time job & $6 \%$ & 7 & $3 \%$ & 7 & $4 \%$ & 14 \\
\hline Care for family & $1 \%$ & 1 & $1 \%$ & 1 & $1 \%$ & 2 \\
\hline Place on a training scheme & $0 \%$ & 0 & $1 \%$ & 3 & $1 \%$ & 3 \\
\hline Travel & $0 \%$ & 0 & $2 \%$ & 5 & $2 \%$ & 5 \\
\hline Don't know & $5 \%$ & 6 & $7 \%$ & 15 & $6 \%$ & 21 \\
\hline Other & $0 \%$ & 0 & $1 \%$ & 3 & $1 \%$ & 3 \\
\hline
\end{tabular}

The patterning of responses is shared across both schools, although the differences are more marked in Applebee, the school with the more intensive widening participation scheme, e.g. $67 \%$ of girls in Applebee aspire to university, compared to $34 \%$ of boys ${ }^{8}$, and the proportion who want to go to university falls from $62 \%$ to $40 \%$ between S2 and S4 ${ }^{9}$. Indeed, whereas in S2 more pupils in Applebee expressed an aspiration for

8 Chi-square $=12.203$; d.f. $=2$; No. of cells with E.F. $<5=0$; Significance $=0.002$. Cases $=$ 108

9 Chi-square $=5.042 ;$ d.f. $=2$; No. of cells with E.F. $<5=0$; Significance $=0.080$. Cases $=107$. 
university (62\%, compared to 57\% for Shepherdton), by S4, this has reversed with more pupils from Shepherdton expressing a university aspiration (40\% for Applebee, compared to $49 \%$ for Shepherdton).

It must be noted though that during the interviews pupils from Shepherdton expressed confusion as to what university is and often thought university and college to be the same when asked do you know the different between college and university

... no really, universities... is it not harder to get in and it's harder things [to study] and you need to be more intelligent? I don't know I'm not sure, no idea really. Is university more up to yourself? (Shepherdton, male, S4).

\section{Networks of Influence}

The research explored who was perceived to be supportive in helping young people making post-school choices. From a capability perspective, it considers the influence of the social arrangements (school, intervention) and environmental factors (parents and families).

Figure 2: Networks of Influence supporting young people to make positive post-school choices (Campbell, 2016).

(Insert Figure 2 about here)

Interestingly, it is environmental factors - and in particular parental influence - that is perceived by young people to be 'most helpful' in assisting them to make their 
decisions; more than one quarter considered their parents to be 'fairly helpful’ (28\%), with more than one-half of young people considering their parents to be 'very helpful' (57\%). Formal social arrangements - in the form of the university-school projects and careers advice' were considered relatively less helpful. It is also prudent to note that many more young people were unable to offer an opinion over the helpfulness of these social arrangements to their decision-making with, for example, one in three responding that they “didn’t know” how helpful careers advisors were in this respect (don’t know data are discounted in Figure 2).

There was little variation between schools and across genders and age-stages for most realms of influence. On the other hand, girls were marginally more likely than boys to consider that the Applebee intervention had been helpful (48\% of girls, compared to $24 \%$ of boys ${ }^{10}$ ). More marked differences of opinion were expressed over the influence of friends, with those from Applebee (relative to Shepherdton), S2 (relative to S4) and girls (relative to boys) being more likely to consider that their friends had been helpful ${ }^{11}$. On further analysis, when controlling for school, the weaker gender differences persist across boys’ schools (girls more likely than boys to consider friends to be helpful in each school, whereas the differences by age-stage are only

${ }^{10}$ Chi-square $=5.030$; d.f. $=1$; No. of cells with E.F. $<5=0$; Significance $=0.025$. Cases $=82$.

${ }^{11} 67 \%$ of those from Applebee, compared to 52\% of those from Shepherdton; 64\% of those from S2, compared to $51 \%$ of those from S4; and $63 \%$ of girls, compared to $53 \%$ of boys. Differences are significant at the 95\% confidence level for school and age-stage and at the $90 \%$ confidence level for gender. 
evident in Shepherdton (62\% of S2 find their friends helpful in this regard, compared to $43 \%$ of S4 pupils ${ }^{12}$ ) and not Applebee (69\% of S2 and 65\% of S4 pupils are considered to be helpful). Thus, the key issue to consider here is the reasons for the perceived weakening of influence of friends as young people progress through Shepherdton and in what way do these changes in the social context influence pupils conversion factors? The qualitative evidence sheds light on this question. The majority of S4 interviewees did not see friends as influential (13 out of 17). Pupils in S2 were much less decisive with 50 percent of interviews taking the same view (7 out of 14). The reasons, which were similar for all, are demonstrated through the following extracts:

sometimes cause I like to have a best friend and we've spent out whole lives together (Applebee, female, S2)

Sometimes yeah, we all want to do the same sort thing, and we talk about it and help each other. We want to kinda stay friends when we leave school (Shepherdton, male, S2)

No. not at all no it's up to them to figure out what they want to do (Applebee, female, S4)

no I mean your friends change I'll make new friends, a lot of people tell me that the friends you end up with won't be the friends you had at school so I don't really

${ }^{12}$ Chi-square $=7.525$; d.f. $=1$; No. of cells with E.F. $<5=0$; Significance $=0.006$. Cases $=$ 199. 
base anything around what they are doing, I mean aye they're my friends but we will want different things when we're older (Shepherdton, male, S4)

It is clear that pupils from S4 are exercising agency to some extent by becoming less reliant on their friends during the decision-making process. However, this agency does not extend to the influence of parents who remain central to the decision-making process.

\section{Conclusion}

The Capability Approach has been deployed as a tool to appraise the non-participation of young people in Higher and Further education, informing understanding of the role of individual agency, the impact of others, and the role of the social arrangements in capability and aspiration formation. In terms of agency, the data highlights that not only do young people from deprived communities aspire for higher education but that they are also confident in the acquisition of most of the capabilities that Walker suggests are required for success in HE. Mostly they are confident in some areas such as engagements, participation, and aspiration formation, yet they continue to lack confidence and self-efficacy. Applying the Capability Approach as a framework for examining this issue allows for the identification of any constraints within the capability set that may impact on aspiration formation. Previous research suggests that selfefficacy, confidence levels, motivation, and perception of learning are key to improving positive destinations. These findings are consistent with past studies that have reported low confidence levels (Reay et al., 2010; Johnson et al., 2007) and a lack of resilience 
(Hutchings and Archer, 2001) as barriers to participation. Thus, it is a useful tool for examining issues of non-participation in depth, by allowing for the identification of agency-specific characteristics that can enable or constrain capability development or aspiration formation.

Parents and family members are considered by young people to exert the strongest influence in helping them make post-school choices, once more confirming earlier research (Goodman and Greggs, 2010; Cuthbert and Hatch, 2009; Atherton et al., 2009), but contrasting the institutional focus on many university-school interventions. This is not to undermine the importance of these 'social arrangements'. Rather, these are instrumental in increasing opportunities for agency freedom. In particular, sustained engagement (as evidenced in Appleton) seems to have a positive impact in supporting young people to make positive post-school choices. Not only did young people report an increase of awareness in what university was but they had a richer understanding of the various aspects of academic life. Thus, using the Capability Approach as a framework has identified that access to resources can enable or constrain a young person’s opportunity to achieve functionings, supporting Sen’s (1999) claim that policymakers need to consider evaluation a space of capabilities rather than utilities.

To conclude, this paper has challenged the primacy of the 'poverty of aspirations thesis' by using the Capability Approach as a framework to re-evaluate the underparticipation of young people from deprived communities in Higher and Further Education. The findings conclude that young people have high aspirations and are confident in their capabilities, which challenges the current policy climate that focuses 
on raising aspirations. Furthermore, by using the Capability Approach as an evaluatory framework, it can be surmised that additional social arrangements are beneficial in helping young people from deprived communities make positive post-school choices. This is particularly evident concerning access to intervention programmes. The Capability Approach framework makes it clear that although aspirations are a critical capability toward achieving functionings, aspirations alone are far from sufficient to widen participation in Higher Education. Although this study is small scale, the mixed methods approach has demonstrated the use of the Capability Approach as a tool for evaluating non-participation and highlighted the positive impact of widening access initiatives. Policy makers should focus future work on capability formation rather than 'raising aspirations'. 


\section{References}

Archer, L., (2007). Diversity, equality, and higher education: a critical reflection on the ab/uses (of equity discourse within widening participation. Teaching in Higher Education, 12(5-6), pp. 635-653.

Atherton, G., Cymbir, E., Roberts, K., Page, L. and Remedios, R., (2009). How young people formulate their views about the future: exploratory research. DCSFRR152. Westminster: Department for Children, Schools, and Families.

Bauman, Z., (1998). Work, Consumerism, and the New Poor. Buckingham: Open University Press.

Biggeri, M., Ballet, J. and Comim, F., (2010). The Capability Approach and research on children: Capability Approach and children's issues. Children and the Good Life. Springer, pp. 75-89.

Brown, G., (2013). The Revolt of Aspirations: Contesting Neoliberal Social Hope. An International E-Journal for Critical Geographies, 12 (3), pp. 419-430.

Brown, G., (2011). Emotional geographies of young people's aspirations for adult life. Children's Geographies, 9(1), pp. 7-22.

Buckley, A. (2013) Engagement for enhancement: Report of a UK survey pilot. York: Higher Education Academy.

Burchardt, T. and Vizard, P., 2011. 'Operationalizing' the capability approach as a basis for equality and human rights monitoring in twenty-first-century Britain. Journal of Human Development and Capabilities, 12(1), pp. 91-119.

Burke, P.J., (2012). The Right to Higher Education: Beyond widening participation. Oxford: Routledge.

Bok, J. (2010). The capacity to aspire to higher education: 'It's like making them do a play without a script.' Critical Studies in Education, 51(2), pp. 163-178.

Campbell, L.A. Aspirations are not enough or enhancing the capability to succeed? Who or what shapes the post-school choices of young people from deprived communities in Scotland (unpublished doctoral thesis, Glasgow Caledonian University, 2016)

Connor, H., Dewson, S., Tyers, C., Eccles, J., Regan, J., and Aston, J., (2001). Social Class and Higher Education: Issues Affecting Decisions on Participation by Lower Social Class Groups. HMSO: London. 
Constantine, N.A., and Benard, B., (2001). California healthy kids survey resilience assessment module: Technical report. Journal of Adolescent Health, 28(2), pp.122-140.

Copestake, J., and Camfield, L., (2010). Measuring Multidimensional Aspiration Gaps: A Means to Understanding Cultural Aspects of Poverty. Development Policy Review, 28(5), pp. 617-633. Croll, P., (2009). Educational participation post-16: A longitudinal analysis of intentions and outcomes. British Journal of Educational Studies, 57.4, pp. 400-416.

Cummings, C., Laing, K., Law, J., McLaughlin, J., Papps, I., Todd, L. and Woolner, P., (2012). Can Changing Aspirations and Attitudes Impact on Educational Attainment? A review of interventions. York: Joseph Rowntree Foundation.

Cuthbert, C., and Hatch, R., (2009). Educational Aspiration and attainment amongst young people in deprived communities, Social Policy Association conference 29th June-1st July (2009).

Department for Education and Skills (DFES), (2005). Excellence in Cities. RR675A. London: Department for Education and Schools.

Education Scotland, (2015), My School. Parentzone. Available: http://www.educationscotland.gov.uk/parentzone/myschool/index.asp

Education Scotland (2016) Attainment and Leaver Destination Statistics Supplementary Data, 2014/15. http://www.gov.scot/Topics/Statistics/Browse/SchoolEducation/leavedestla/follleavedestat

Gale, T., \& Parker, S. (2015). Calculating student aspiration: Bourdieu, spatiality and the politics of recognition. Cambridge Journal of Education, 45(1), pp. 81-96.

Goodman, A. and Gregg, P. eds., (2010). Poorer children's educational attainment: how important are attitudes and behaviour? (p. 6). York: Joseph Rowntree Foundation.

Goodman, R., (1997). The Strengths and Difficulties Questionnaire: a research note. Journal of Child Psychology and Psychiatry, 38(5), pp. 581-586.

Gutman, L.M. and Akerman, R., (2008). Determinants of aspirations. Centre for Research on the Wider Benefits of Learning, Institute of Education, University of London.

Hart, C., (2007). The capability approach as an evaluative and developmental framework for education policy: the example of widening participation in higher education in England. Prospero, 13(3), pp. 34-50. 
Hart, C.S., (2008). What Can Young People Tell Us about Promoting Equality and Inclusion through widening participation in Higher Education in England? Human Development and Capability Association International Conference, 913th September (2008), University of Cambridge, pp. 1-14.

Hart, C.S., (2009). Quo Vadis? The capability space and new directions for the philosophy of educational research. Studies in Philosophy and Education, 28(5), pp. 391-402.

Hart, C.S., (2012a). Aspirations, Education, and Social Justice: Applying Sen and Bourdieu. London: Bloomsbury Academic Publishing Ltd.

Hart, C.S., (2012b). Closing the Capabilities Gap: Renegotiating Social Justice for the Young. Journal of Human Development and Capabilities, 13(3), pp. 513-515.

Hart, C. S. (2016). How Do Aspirations Matter? Journal of Human Development and Capabilities, 17(3), 324-341.

HM Treasury. (2007. Aiming high for young people: a ten-year strategy for positive activities. London: HM Treasury.

Hollywood, E., Egdell, V., Mcquaid, R. and Michel-Schertges, D., (2012).

Methodological issues in operationalising the Capability Approach in empirical research: an example of cross-country research on youth unemployment in the EU. Social Work \& Society, 10(1).

Hutchings, M., and Archer, L., (2001). Higher than Einstein: Constructions of Going to University among Working-class Non-respondents. Research Papers in Education. 16(1), pp. 69-91.

Johnson, D.R., Soldner, M., Leonard, J.B., Alvarez, P., Inkelas, K.K., Rowan-Kenyon, H.T. and Longerbeam, S.D., (2007). Examining sense of belonging among firstyear undergraduates from different racial/ethnic groups. Journal of College Student Development, 48(5), pp. 525-542.

Keating, M. (2005). Higher education in Scotland and England after devolution. Regional and Federal Studies, 15(4), 423-435.

Kintrea, K., St.Clair, R. and Houston, M., (2011). The influence of parents, places and poverty on educational attitudes and aspirations. Glasgow: Joseph Rowntree Foundation.

MacKinnon, D. (2015). Devolution, state restructuring and policy divergence in the UK. The Geographical Journal, 181(1), 47-56. 
McKendrick, J.H., Scott, G., \& Sinclair, S. (2007). Dismissing disaffection: young people's attitudes towards education, employment, and participation in a deprived community. Journal of Youth Studies, 10(2), 139-160.

Millburn, A., (2009). Unleashing aspiration: the final report of the panel of fair access to the professions. B12753. London: Cabinet Office.

National Committee of Inquiry into Higher Education, (1997). Higher Education in the Learning Society (The Dearing Report). HMSO: London.

Nussbaum, M., (2000). Women and Human Development: the capabilities approach Cambridge: Cambridge University Press.

Nussbaum, M., (2011). Creating Capabilities. Boston: Harvard University Press.

Parker, R., (2012). Unlocking Scotland's Potential. Edinburgh: NUS Scotland.

Public Accounts Committee, (2009). Widening participation in higher education: Fourth Report of Session (2008)-09. London: House of Commons.

Reay, D., Crozier, G. and Clayton, J., (2010). 'Fitting in' or 'standing out': workingclass students in UK higher education. British Educational Research Journal, 36(1), pp. 107-124.

Robeyns, I., (2005). The capability approach: a theoretical survey. Journal of Human Development, 6(1), pp. 93-117.

Scottish Funding Council (2015). Participation indicators for Scottish HEIs (20142015). Available:

http://www.sfc.ac.uk/PublicationsStatistics/statistics/higher_education_statistics/ HE_performance_indicators/Participation_indicator_for_Scottish_HEIs.aspx [Accessed 20/12/2015].

Scottish Funding Council (2016). Universities: Progress and Ambitions. Summary of Progress 2015-16. Edinburgh: SFC.

Scottish Government (2016). Scottish Index of Multiple Deprivation. Available: http://www.gov.scot/Topics/Statistics/SIMD [Accessed 02/08/2016]

Sellar, S. (2015). 'Unleashing aspiration': The concept of potential in education policy. The Australian Educational Researcher, 42(2), pp. 201-215.

Sellar, S., Gale, T., \& Parker, S. (2011). Appreciating aspirations in Australian higher education. Cambridge Journal of Education, 41(1), pp. 37-52.

Sen, A., (1992). Inequality re-examined. Oxford: Clarendon Press.

Sen, A., (1999). Development as freedom (1st Ed.). New York: Oxford University Press. 
Sen, A., (2004) Capabilities, Lists, and Public Reason: Continuing the Conversation, Feminist Economics, 10:3, pp. 77-80.

Shildrick, T., MacDonald, R., \& Furlong, A. (2016). Not single spies but in battalions: a critical, sociological engagement with the idea of so-called 'Troubled Families.' The Sociological Review. DOI: 10.1111/1467-954X.12425

Schischka, J, (2014). Evaluating Children's Capabilities Enhancement in Schools. In: Hart, C.S., Biggeri, M. and Babic, B. eds., 2014. Agency and participation in childhood and youth: International applications of the capability approach in schools and beyond. A\&C Black, pp. 163-180

Sinclair, S., McKendrick, J. H., \& Scott, G. (2010). Failing young people? Education and aspirations in a deprived community. Education, Citizenship and Social Justice, 5(1), 5-20.

Social Exclusion Task Force, (2008). Aspiration and attainment amongst young people in deprived communities. Department for Schools, Children’s and Families.

Spohrer, K. (2011). Deconstructing ‘Aspiration’: UK policy debates and European policy trends. European Educational Research Journal, 10(1), pp. 53-63.

Spohrer, K. (2015). Negotiating and contesting 'success': discourses of aspiration in a UK secondary school. Discourse: Studies in the Cultural Politics of Education, pp. 1-15.

St Clair, R. and Benjamin, A., (2011). Performing desires: the dilemma of aspirations and educational attainment. British Educational Research Journal, 37(3), pp. 501-517.

Stewart, F., (2005). Groups and Capabilities. Journal of Human Development, 6(2), pp. 185-204.Strand, S. (2014). Ethnicity, gender, social class and achievement gaps at age 16: Intersectionality and 'Getting it'for the white working class. Research Papers in Education, 29.2, pp. 131-171.

Terzi, L., (2007). The Capability to be Educated. In: M. Walker and E. Unterhalter, (Eds), Amartya Sen's Capability Approach and Social Justice in Education. New York: Palgrave Macmillan, pp. 25-44.

Walker, M., (2006). Higher education pedagogies. Buckingham: Open University Press.

Walker, M., and Unterhalter, E., (2007). Amartya Sen's Capability Approach and Social Justice in Education. ed. London: Palgrave. 
Watts, M., and Bridges, D., (2006). The value of non-participation in higher education. Journal of Education Policy, 21(3), pp. 267-290.

Woodrow, M., Lee, M.F., McGrane, J., Osborne, B., Pudner, H. and Trotman, C., (1998). From Elitism to Inclusion: Good Practice in Widening Access to Higher Education, Main Report. London: CVC

Ysander, B., (1993). Descriptions of inequality. In Nussbaum M., Sen, AK (Eds), The Quality of Life. London: Clarendon Press.

Zipin, L., Sellar, S., Brennan, M., \& Gale, T. (2015). Educating for Futures in Marginalized Regions: A sociological framework for rethinking and researching 